\title{
PENGETAHUAN DAN KEBIASAAN MEMBACA LABEL INFORMASI NILAI GIZI MAKANAN KEMASAN TIDAK BERHUBUNGAN DENGAN STATUS GIZI PADA MAHASISWA ASRAMA KUTAI KARTANEGARA DI YOGYAKARTA
}

\author{
Nurul Fitri ${ }^{1 *}$, Metty ${ }^{1}$, Endri Yuliati ${ }^{1}$ \\ Program Studi Gizi Program Sarjana, Fakultas Ilmu Kesehatan, Universitas Respati Yogyakarta \\ Email korespondensi ululbilly@gmail.com
}

\begin{abstract}
Background: The results of a National Consumer Protection Agency study in 2007 revealed only $6.7 \%$ of consumers in Indonesia pay attention to labels on packaged food. Even though the label information on the nutritional value of packaged food is very important to consider to improve and maintain good nutritional status for health. Objective: To know the relationship between knowledge and habits of reading label information on nutritional value of packaged foods with nutritional status in the Kutai Kartanegara dormitory. Methods: This research was observational with cross sectional design. This study used total population, which were 41 students in the Kutai Kartanegara dormitory. Knowledge and habits were assesed using questionnaire, while nutritional status was measured using BMI indicators. Statistical analysis was conducted using the Fisher Exact test. Results: Most of the respondents $(82.9 \%)$ had good knowledge but the majority $(68.3 \%)$ had less habits, related to the nutritional status of the majority $(73.2 \%)$ were normal BMI. There was relationship between the knowledge of reading labels on the nutritional value of packaged food with nutritional status ( $p$-value $=$ 0.388 ) as well as the habit of reading the label nutritional value and packaged food and nutritional status $(p$-value $=0.497)$. Conclusion: There were no relationship between knowledge and habits of reading nutritional information label on packaging food.
\end{abstract}

Keywords: Knowledge, Habits, Information Labels on Food Packaging, Nutritional Status.

Pangan merupakan salah satu bahan pokok dalam rangka pertumbuhan /kehidupan bangsa, serta mempunyai peranan penting dalam pembangunan nasional (1). Secara nasional, prevalensi makanan berisiko yang paling banyak dikonsumsi oleh penduduk berusia $>10$ tahun adalah pangan berpenyedap $(77,8 \%)$, manis $(68,1 \%)$, berkafein $(36,5 \%)$ dan asin $(24,5 \%)$. Membiasakan membaca label pangan kemasan merupakan salah satu pesan dalam Pedoman Gizi Seimbang. Label pangan kemasan berisi sekurang-kurangnya tujuh informasi, yaitu nama produk, berat bersih atau isi bersih, nama dan alamat pihak yg memproduksi atau memasukkan pangan ke dalam wilayah Indonesia, komposisi atau daftar bahan, keterangan kadaluarsa, nomor pendaftaran, tanggal dan atau kode produksi. Dengan demikian, membaca label dapat membantu konsumen dalam memilih pangan yang aman dan sesuai dengan kebutuhannya. Namun, sebenarnya konsumen dapat membatasi pangan tersebut dan memilih pangan yang sesuai dengan kebutuhannya, jika cermat mengenalinya melalui label pada kemasan pangan.

Di Indonesia berdasarkan data Badan Perlindungan Konsumen Nasional (BPKN) pada tahun 2007, mengungkapkan bahwa 6,7\% konsumen di Indonesia yang memperhatikan label dalam memilih produk makanan. Rendahnya kebiasaan membaca label pangan membuat konsumen memilih makanan yang tidak sehat sehingga menurunkan kondisi kesehatan. 
Mereka yang tidak membaca label pangan mengonsumsi lebih tinggi lemak kolesterol, dan gula dibandingkan dengan yang membaca label (2).

Kepatuhan membaca label informasi dan zat gizi yang rendah terjadi karena hambatan usaha pencarian informasi. Salah satu penghambat adalah ketidaktertarikan terhadap informasi yang dapat disebabkan oleh pemahaman tentang label yang kurang. Informasi pada label zat gizi dan komposisi jauh lebih banyak dan kompleks. Selain itu, istilah yang digunakan sulit dan tidak akrab didengar masyarakat. Banyak konsumen yang tidak yakin dengan informasi zat gizi yang penting. Beberapa responden merasa kurang yakin tentang konsumsi zat gizi seperti gula, garam, dan lemak akan berdampak pada kesehatan beberapa responden diketahui tidak akrab dengan istilah dalam pelabelan gizi seperti sodium.

Rendahnya kebiasaan membaca label pangan membuat konsumen memilih makanan yang tidak sehat sehingga menurunkan kondisi kesehatan. Mereka yang tidak membaca label pangan mengonsumsi lebih tinggi lemak kolesterol, dan gula dibandingkan dengan yang membaca label (3). Penelitian tersebut mengungkapkan bahwa $53,1 \%$ responden perempuan membaca label produk pangan dibandingkan dengan responden laki-laki yang hanya 19,2\%. Selain itu 52,4\% responden yang berpendidikan di atas SLTP membaca label produk pangan dibanding hanya $28,9 \%$ responden yang berpendidikan di bawah SLTP, dan 49,5\% responden yang bekerja, membaca label produk pangan di banding hanya $23,8 \%$ responden yang tidak bekerja.

Mahasiswa menjadi konsumen penting bagi pelaku bisnis dalam menjual berbagai makanan termasuk makanan kemasan. Mahasiswa sebagai konsumen harus pintar dalam memilih produk makanan karena banyaknya makanan kemasan yang rusak, dan lain-lain. Oleh karena itu, peneliti tertarik untuk melihat hubungan pengetahuan dan kebiasaan dalam membaca label informasi nilai gizi pada kemasan makanan dengan status gizi pada kalangan mahasiswa.

\section{METODE}

Penelitian ini merupakan penelitian observasional dengan pendekatan kuantitatif. Desain penelitian ini adalah cross sectional. Penelitian ini dilaksanakan pada bulan Oktober 2019 di asrama mahasiswa kutai kartanegara di Yogyakarta. Subjek penelitian berjumlah 41 orang. Pengambilan sampel menggunakan teknik total populasi. Data pengetahuan dan kebiasaan diukur dengan kuesioner pengetahuan dan kebiasaan. Kuesioner yang digunakan sudah melalui uji expert dengan nilai (85\%) sedangkan status gizi diukur dengan indikator IMT.

Kriteria inklusi adalah mahasiswa asrama kutai kartanegara yang berusia usia 18-25 tahun. Proses pengambilan data dimulai dengan menjelaskan tujuan penelitian kepada responden kemudia meminta kesediaan mahasiswa untuk menjadi responden. Kesediaan ditunjukkan dengan menandatangani surat persetujuan menjadi responden. Kuesioner pengetahuan dan kebiasaan dalam membaca label informasi nilai gizi diisi sendiri oleh responden sedangkan pengukuran berat dan tinggi badan dilakukan oleh mahasiswa gizi yang sudah terlatih. Penilaian kuesioner pengetahuan dilakukan dengan : nilai 0 jika jawaban salah dan 1 jika jawaban benar. Untuk kuesioner kebiasaan membaca label informasi nilai gizi makanan kemasan pada item pertanyaan unfavorabel, diberi nilai 0 jika tidak pernah, 1 jika jarang, dan 2 jika sering sedangkan untuk pertanyaan favorabel diberi nilai 0 jika sering, 1 jika jarang, dan 2 jika tidak pernah. Status gizi ditentukan berdasar IMT dengan 
menggunakan rumus = berat badan $(\mathrm{kg})$ /tinggi badan $(\mathrm{m})^{2}$. Analisis statistik menggunakan uji Fisher Exact karena ada sel table yang tidak memenuhi syarat untuk uji chi square. Penelitian ini sudah mendapatkan surat kelayakan etika dari komisi Etika Universitas Respati Yogyakarta : 296.3/FIKES/PL/IX/2019.

\section{HASIL}

Karakteristik responden yang dikaji dalam penelitian ini meliputi usia mahasiswa, jenis kelamin dan pendidikan mahasiswa dapat dilihat pada Tabel 1.

Tabel 1. Karakteristik Subjek Penelitian

\begin{tabular}{ccc}
\hline $\begin{array}{c}\text { Karakteristik } \\
\text { Responden }\end{array}$ & $\mathbf{n}$ & $\%$ \\
\hline Umur & & \\
18-20 Tahun & 16 & 39,0 \\
$21-25$ Tahun & 25 & 61,0 \\
Jenis Kelamin & & \\
Laki-laki & 23 & 56,1 \\
Perempuan & 18 & 43,9 \\
Jenjang & & \\
Pendidikan & & \\
D3 & 3 & 7,3 \\
S1 & 36 & 87,8 \\
S2 & 2 & 4,9 \\
\hline Total & $\mathbf{4 1}$ & $\mathbf{1 0 0 , 0}$ \\
\hline & & \\
\hline
\end{tabular}

Dapat diketahui bahwa umur responden yang berusia 21-25 tahun sebanyak 61,0\%. Jenis kelamin terbanyak adalah laki-laki $(56,1 \%)$, dan pendidikan responden terbanyak adalah S1 $87,8 \%$. (Tabel.1)

Tabel.2 Pengetahuan dan Kebiasaan Mahasiswa Mengenai Membaca Label dan Status Gizi Subjek Penelitian

\begin{tabular}{ccc}
\hline Variabel & $\mathbf{n}$ & $\%$ \\
\hline Pengetahuan & & \\
Kurang & 3 & 7,3 \\
Cukup & 4 & 9,8 \\
Baik & 34 & 82,9 \\
Kebiasaan & & \\
Kurang & 28 & 68,3 \\
Cukup & 7 & 17,1 \\
Baik & 6 & 14,6 \\
Status Gizi & & \\
Kurus & 3 & 7,3 \\
Normal & 30 & 73,2 \\
Gemuk & 9 & 22,0 \\
\hline Total & $\mathbf{4 1}$ & $\mathbf{1 0 0 , 0}$ \\
\hline
\end{tabular}


Berdasarkan pengetahuan mahasiswa mengenai membaca label informasi nilai gizi makanan kemasan sebagian besar yaitu 34 orang $(82,9 \%)$ responden memiliki pengetahuan dalam kategori baik. Berdasarkan kebiasaan mahasiswa mengenai membaca label informasi nilai gizi makanan kemasan, sebagian besar $(68,3 \%)$ dengan kategori kurang. Berdasarkan status gizi, sebagian besar responden $(73,2 \%)$ dengan kategori normal. (Tabel.2)

Tabel 3. Hubungan Pengetahuan dan Kebiasaan Membaca Label Informasi Nilai Gizi Makanan dengan Status Gizi

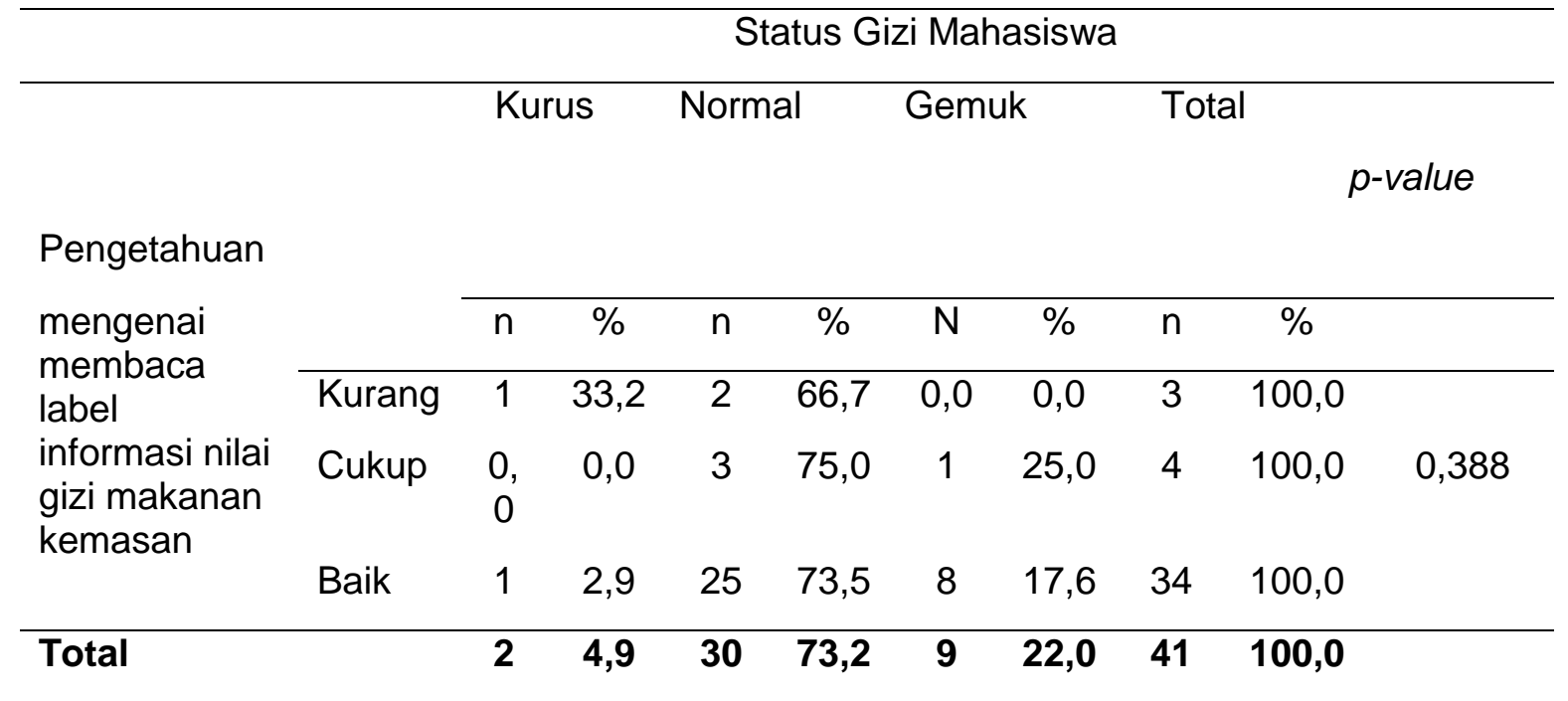

Sebanyak 34 responden yang memiliki pengetahuan mengenai membaca label informasi nilai gizi makanan kemasan yang baik, terdapat $1(2,9 \%)$ mahasiswa dengan status gizi kurus, $25(73,5 \%)$ normal dan $8(17,6 \%)$ status gizi gemuk. Hasil uji fisher exact didapatkan nilai $p$ - value $0,388(p<0,05)$, artinya tidak ada hubungan antara pengetahuan membaca label informasi nilai gizi makanan kemasan dengan status gizi. (Tabel.3)

Tabel.4 Hubungan Kebiasaan Membaca Label Informasi Nilai Gizi Makanan dengan Status Gizi

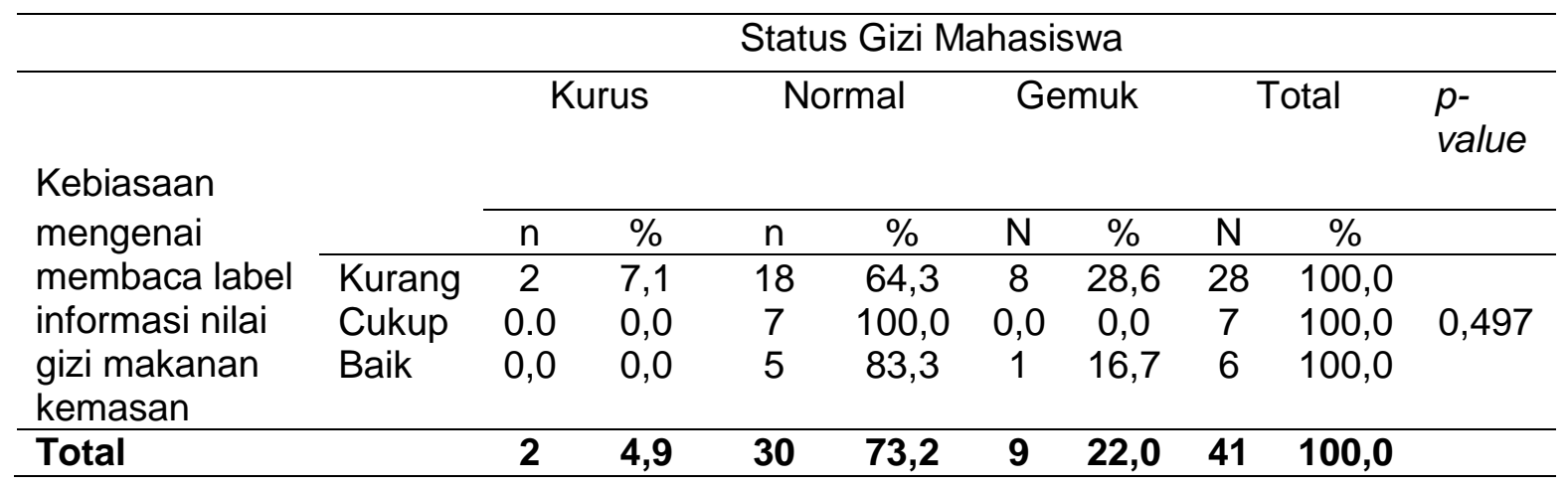


Dari 28 responden yang memiliki kebiasaan mengenai membaca label informasi nilai gizi makanan kemasan yang kurang terdapat 2 (7,1\%) dengan status gizi kurus, 18 (64,3\%) status gizi normal, dan $8(28,6 \%)$ status gizi gemuk.

Hasil uji fisher extract didapatkan nilai $p$ - value $0,497(p<0,05)$, artinya tidak ada hubungan antara kebiasaan mahasiswa membaca label informasi nilai gizi makanan kemasan dengan status gizi. (Tabel.4) 


\section{PEMBAHASAN}

\section{Karakteristik Responden}

Rentang usia 18-25 tahun merupakan usia yang paling umum dimiliki seseorang dengan status mahasiswa $\mathrm{S} 1$ dan tergolong dalam usia dewasa muda. Hal ini menunjukan bahwa masa dewasa awal pada seseorang dikatakan mencapai maturitas ketika mereka sudah mencapai keseimbangan pertumbuhan fisiologis, psikososial, dan kognitif. Individu pengetahuan, dan respon yang telah mereka kembangkan selama bertahun-tahun. Mereka memiliki dunia dengan pandangan yang luas, berdasarkan penglihatan, emosi, dan imajinasi (4). Tahapan dalam pertumbuhan dan perkembangan adalah remaja (12-20 tahun) dan dewasa awal (20-40 tahun).

Umur menggambarkan kematangan fisik, psikis dan sosial yang mempengaruhi proses belajar mengajar. Ini berarti bahwa usia merupakan salah satu faktor yang mempengaruhi informasi yang pada akhirnya berpengaruh pada peningkatan pengetahuan seseorang. Hal ini menunjukan bahwa pada usia dewasa awal seseorang memiliki pengetahuan yang baik terlihat ketika mereka mampu mengenal dan memahami suatu informasi misal pengetahuan membaca label informasi nilai gizi makanan kemasan (5).

Diketahui bahwa jenis kelamin terbanyak pada responden adalah laki-laki yaitu sebesar $56,1 \%$. Bahwa stereotipe tentang pria dan wanita berbeda pada beberapa ciri-ciri kepribadian. Pria terlihat lebih agresif, sombong, kompetitif, kasar, kejam, dominan, independen, kasar, dan tidak emosional; wanita terlihat lebih mesra, cemas, penuh kasih, bergantung, emosional, lembut, sensitif, sentimental, dan tunduk. Kedua jenis kelamin juga dilihat sebagai berbeda dalam kepentingan mereka: Anak laki-laki diyakini lebih tertarik pada kegiatan perbaikan mobil, pertukangan, rekayasa, dan anak perempuan dan perempuan lebih teratrik pada keperawatan, menari dan akting, konseling (6). Diketahui bahwa pendidikan terbanyak pada responden adalah $\mathrm{S} 1$ (87,8\%). Hal ini menunjukan bahwa pendidikan berkaitan dengan kemampuan seseorang dalam mencari sumber informasi, semakin banyak informasi yang diperoleh tentang hal-hal yang terjadi. Pendidikan juga mempengaruhi seseorang termasuk pengetahuan dan perilaku kan pola hidup terutama dalam memotivasi untuk sikap berperan serta dalam pembangunan. Pada umumnya semakin tinggi pendidikan seseorang maka semakin mudah seseorang dapat menerima informasi (7).

\section{Pengetahuan Membaca Label Informasi Nilai Gizi Makanan Kemasan}

Pengetahuan mahasiswa membaca label informasi nilai gizi makanan kemasan dilihat dari 34 responden dengan kategori baik $(82,9 \%)$. Sebagian besar responden hanya memperhatikan pengetahuan tentang zat gizi lemak, kolesterol, protein, gula dan natrium secara umum saja dibandingkan dengan pengetahuan zat gizi secara khusus. Hal ini dimungkinkan karena sebagian besar responden belum pernah mendapatkan edukasi mengenai informasi nilai gizi makanan kemasan. Pada saat peneliti menanyakan kepada 3 responden tentang pengetahuan makanan kemasan, hasil menunjukkan bahwa 3 responden melakukan pemilihan makanan kemasan yang salah karena memilih produk yang harganya murah. Alasan yang paling sering adalah responden memilih karena mempertimbangkan kesukaan dari produk saja. 
Tujuan dari pemberian label kemasan pangan adalah agar masyarakat yang membeli dan mengkonsumsinya, memperoleh informasi yang benar dan jelas tentang setiap produk pangan yang dikemas, baik yang menyangkut asal, keamanan mutu, kandungan gizi maupun keterangan lain yang diperlukan, sebelum memutuskan akan membeli atau mengkonsumsi produk pangan tersebut. Oleh sebab itu label memiliki fungsi sebagai bahan pertimbangan bagi konsumen untuk menentukan pilihan (8).

\section{Kebiasaan Membaca Label Informasi Nilai Gizi Makanan Kemasan}

Kebiasaan mahasiswa mengenai membaca label informasi nilai gizi makanan kemasan sebagian besar (68,3\%) dengan kategori kurang ini dikarenakan responden belum menerapkan pengetahuan yang dimiliki dengan membiasakan membaca label informasi nilai gizi makanan kemasan. Responden cenderung hanya memperhatikan beberapa zat gizi yaitu lemak, kolesterol, protein, gula dan natrium ini. Hal ini dimungkinkan karena maraknya penyakit yang lagi berkaitan dengan zat gizi tersebut seperti hipertensi, diabetes, dan kolesterol.

Perilaku adalah bentuk respon atau reaksi terhadap stimulus atau rangsangan dari orang luar, namun dalam memberikan respons sangat tergantung pada karakteristik atau faktor-faktor lain dari orang yang bersangkutan dan perilaku didukung berdasarkan pengetahuan, sikap dan tindakan (9).

\section{Status Gizi}

Berdasarkan tabel 4.2 sebagian besar (73\%) mahasiswa mempunyai IMT normal. Status gizi merupakan hasil dari keseimbangan atau perwujudan dari nutrisi dalam bentuk variabel tertentu (10). Keseimbangan antara asupan dan kebutuhan zat gizi menentukan seseorang tergolong dalam kriteria status gizi tertentu, dan merupakan gambaran apa yang dikonsumsinya dalam rentang waktu yang cukup lama (11).

Faktor-faktor yang dapat mempengaruhi status gizi secara langsung antara lain pola konsumsi makanan sehari-hari, aktivitas fisik, dan keadaan kesehatan. Selain itu juga faktor yang mempengaruhi status gizi secara langsung adalah pendapatan, pendidikan orang tua dan kebiasaan makannya (12). Penelitian lain yang dilakukan pada mahasiswa di asrama universitas andalas menunjukan bahwa $8,4 \%$ responden memiliki status gizi buruk, mayoritas responden $(59,8 \%)$ telah memiliki pengetahuan tentang nutrisi yang bagus. Konsumsi energi rata-rata (1.706,62 kkal) dan karbohidrat $(227,56$ gram) masih kurang dari yang disarankan sementara asupan protein (56,49 gram) dan lemak (62,38 gram) sudah sesuai dengan kecukupan yang disarankan (13).

\section{Hubungan pengetahuan membaca label informasi nilai gizi makanan kemasan dengan status gizi}

Dari hasil penelitian diketahui bahwa tidak ada hubungan antara pengetahuan mengenai membaca label informasi nilai gizi makanan kemasan dan status gizi pada mahasiswa ( $p$-value $=0,388$ ). Jumlah responden berpengetahuan baik yang mempunyai 
status gizi normal adalah 25 (73,5\%). Penyebab tidak adanya hubungan antara pengetahuan dengan status gizi adalah karena pengetahuan adalah memberi pengaruh secara tidak langsung terhadap status gizi, tetapi pengetahuan gizi adalah pokok masalah dari permasalahan gizi. Sedangkan penyebab langsung dari masalah gizi adalah asupan gizi dan penyakit infeksi. Di antara penyebab langsung dan pokok masalah ada penyebab tidak langsung yaitu persediaan makanan di rumah, perawatan anak dan ibu hamil dan pelayanan kesehatan. Pokok masalah selain dari pengetahuan juga terdiri dari pendidikan, kemiskinan dan keterampilan dimana akar masalahnya adalah krisis ekonomi langsung (14). Hal ini sejalan dengan penelitian yang dilakukan di negara Korea Selatan pada tahun 2010 menyatakan bahwa masyarakat mengerti dan memahami tentang label informasi gizi namun tidak membaca label informasi gizi (15).

\section{Hubungan kebiasaan membaca label informasi nilai gizi makanan kemasan dengan status gizi}

Dari hasil penelitian diketahui bahwa tidak ada hubungan antara kebiasaan membaca label informasi nilai gizi makanan kemasan dengan status gizi pada mahasiswa ( $p$-value = 0,497). Hampir setengah dari total responden yaitu 45,5\% termasuk dalam kategori tidak memperhatikan label informasi gizi. Kandungan energi merupakan komponen informasi gizi yang paling banyak dibaca ( 29 orang), dan hanya $20 \%$ responden yang memilih untuk tidak membeli makanan kemasan tanpa label gizi (16).

Kebiasaan mahasiswa dalam membaca label informasi nilai gizi makanan kemasan lebih banyak dipengaruhi oleh harga, rasa dan jenis makanan. Walaupun pengetahuan sudah baik, namun masih jarang yang menerapkan kebiasaan membaca label informasi tersebut.

Kebiasaan membaca label informasi nilai gizi makanan kemasan bukan merupakan faktor yang mempengaruhi status gizi mahasiswa, namun kebiasaan tersebut sangat berperan dalam menentukan status gizi mahasiswa. Status gizi bukan semata-mata disebabkan oleh pola pemberian makan melainkan banyak faktor yang mempengaruhi antara lain pendidikan, pendapatan orang tua dan anggota keluarga (17). Penelitian lain menunjukkan bahwa tingkat pengetahuan cara membaca label informasi gizi mahasiswa status gizi normal lebih baik daripada mahasiswa obesitas saat memilih makanan kemasan (12). Penelitian lain yang dilakukan yaitu responden dengan status gizi normal cenderung memilih makanan cepat saji yang baik dibandingkan responden dengan status gizi kurang dan obesitas (18)

\section{KESIMPULAN DAN SARAN}

Tidak terdapat hubungan pengetahuan dan kebiasaan membaca label informasi nilai gizi makanan kemasan dengan status gizi di kalangan mahasiswa asrama kutai kartanegara di Yogyakarta. Diharapkan mahasiswa dapat meningkatkan pengetahuan dan kebiasaan membaca label informasi nilai gizi makanan kemasan. Pengelola asrama dapat memberikan edukasi terkait Kesehatan, khususnya terkait pentingnya memperhatikan label informasi nilai gizi pada makanan kemasan. 


\section{UCAPAN TERIMA KASIH}

Peneliti mengucapkan terima kasih kepada seluruh mahasiswa asrama kutai kartanegara di Yogyakarta atas bantuan dan kesempatan yang diberikan sehingga bisa melakukan penelitian ini.

\section{DAFTAR PUSTAKA}

1. Asmaiyar. 2004. Faktor - Faktor yang Berhubungan dengan Kepatuha Konsumen Membaca Label Produk Pangan di Pasar Kebayoran Lama:Jakarta Selatan Tahun 2003. Tesis FKM UI.

2. Guthrie, JF., Fox JJ., Cleveland LE, \& Welsh S. 1995.Who uses nutrition labeling, and what effects does label use have on diet quality. Journal of Nutrition Education, 27, $163-$ 2.

3. Guthrie, JF., Derby, BM., \& Levy AS. 1999. What people know and do not know about nutrition. Dalam American's eating habits: Changes and consequences. $243-0$.

4. Potter \& Perry. 2005. Buku Ajar Fundamental Keperawatan. Jakarta: EGC.

5. Kemenkes RI. 2008. Tentang Standar Antropometri Penilaian Status Gizi Anak. Riset Kesehatan Dasar 2007, Jakarta : Badan Penelitian Dan Pengembangan Kesehatan. 2010

6. Lippa \& richard A. 2010: Gender Differences in Personality and Interests: When, Where, and Why. California: Blackwell Publishing.

7. Wawan \& Dewi, 2010, Teori dan Pengukuran Pengetahuan, Sikap dan Perilaku Manusia. Yogyakarta : Nuha Medika

8. Mediani NV, 2014, Pengetahuan Persepsi Sikap dan Perilaku Membaca Label Informasi Gizi pada Mahasiswa, Institut Pertanian Bogor, Bogor.

9. Moniharapon, E.1998. Analisis Klaim Iklan dan Label Pada Produk Pangan. Tesis Pasca Sarjana. Jurusan Gizi Masyarakat dan Sumber Daya Keluarga, Fakultas Pertanian, Institut Pertanian Bogor.

10. Supariasa. 2014. Penilaian Status Gizi. Jakarta: EGC

11. Siti, Z \& Triyanti, 2009. Kepatuhan Membaca Label Informasi Zat Gizi di Kalangan Mahasiswa : Departemen Gizi Fakultas Kesehatan Masyarakat Universitas Indonesia.

12. Anggraini, S, Handayani D \& Kusumastuty I, 2018. Tingkat Pengetahuan Cara Membaca Label Informasi Gizi Mahasiswa Status Gizi Normal Lebih Baik Dibandingkan Mahasiswa Obesitas : Universitas Brawijaya Malang, Vol.5 No.2

13. Elnovriza, D., Bachtiar, H., \& Yenrina. 2009. Hubungan pengetahuan Dan Asupan Zat Gizi Dengan Status Gizi Mahasiswa Diasrama Universitas Andalas, Jurnal Kesehatan Masyarakat, September 2009 - Maret 2010, Vol. 4, No. 1

14. Supariasa. 2012. Pendidikan Dan Konsultasi Gizi. Jakarta : EGC

15. Arikunto, S. 2010. Metode Penelitian Kualitatif. Jakarta: Bumi Aksara

16. Palupi, I R., Naomi, N D., \& Susilo, J. 2017 , Penggunaan Label Gizi dan Konsumsi Makanan Kemasan pada Anggota Persatuan Diabetes Indonesia, Kesehatan Mayarakat : Jurnal Kesehatan Masyarakat. Vol. 11, No, 1, March 2017,pp, 1-8

17. Lee A K, Lee H J, dan Park E 2010, The Effect of Use of Nutrition Labelling on Knowledge and Perception of Nutrition Labelling and Awarenes of Nutrition Labelling Usefulnes 
GIZIDO Volume 12. No 1 Mei 2020 Pengetahuan dan Kebiasaan Membaca Label Nurul Fitri dkk with among College Students, Jurnal Korean Social Food Science Nutrition (39) : 253-6.

18. Lubis,N. L., 2009. Depresi dan tinjauan psikologis. Jakarta: Prenada Media Groupp 